\title{
Quality of Work Life of Personnel in Computer Designing Field
}

\author{
Er. K.Padminii, Dr. D. Venkatramaraju \\ B.Sc., AMIE, MA, MBA, M.Phil., Ph.D Scholar in Management \\ M.B.A., M.Com. M.A., M.Ed., BGL. M.Phil., Ph.D., A.C.S.INTER \\ Research Guide, Dept. of Management Bharath University,Chennai 600073
}

\begin{abstract}
Computer core field especially Software designing Industries have proven to be the backbone of national development in many countries. India's total expenditure indicates local organizations which are incorporating system analyst into their business activities. The government has prioritized software field as an issue of national importance and established new agencies and policy initiatives to accelerate its implementation and thereby transform India into a developed and knowledge-based country.

Dynamic and continuous developments of technical system and design management have brought significant changes to work condition and work consequences. Therefore, it is essential to examine the Quality of Work Life $(Q W L)$ among the Technical analyst of system design personnel.

This study utilized Job Demand-Control-Support Model to examine the work condition. The results show in the active quadrant that allows them to experience better QWL. Based on regression analysis, it was found that variables of work condition were significant predictors of QWL among Technical analyst of system design personnel.
\end{abstract}

Keywords: Environment, Quality, Employees, IT Sector

\section{Introduction:}

The rapid development in the computer sectors beyond the expectation has created a vacuum in the employment trend. The computer industry in India has enjoyed highest employment growth of $17.2 \%$ in 2003 and is expected to register $23 \%$ growth in 2004 compared to other industries, however, reported that there is an increase in shortage of skilled workforce in the country despite the increased demand for qualified Technical analyst of system design personnel as more and more organizations continue to rely on their effectiveness and competitive advantages.

Many attempts have been made to gain insight of the interaction between the psychosocial work Technical analysts of system design personnel factors and Quality of Work Life (QWL) in system based work organizations. Psychosocial factors are the components of work and organizational characteristics that have an interaction with individual employees. Continuous changes in psychosocial work factors directly or indirectly affected the Technical analyst of system design personnel because these changes demand them to perform. Therefore, it is a responsibility of the organizations to handle and take an effective measure of its consequences as this would attract or retain prospective Technical analyst of system design personnel in the demanding employment trend in the Technical system design industries.

An increasing demand against the limited supply of Technical analyst of system design personnel has forced many organizations to capitalize on small and flexible workforce for maximum organizational performance. It has also created new types of jobs and skills required the way work is being carried out and the relationship between the employees-employers in the organizations. As a result, the employees are expected to undertake ever-expanding work responsibilities. Thus, they have to be responsible for multitasking with higher workload that demands long hours of physical appearance in front of computers. This trend appears to cause exerted pressure and, in certain cases, leads to a dehumanized work environment. This eventually influences the life style of system personnel, which have substantial impact on their QWL. Although its antecedents and outcomes have been researched extensively, little attention has been devoted to understand the work conditions pertaining to QWL as perceived by the Technical analyst of system design personnel particularly in work environment. Work condition as operationalised in this research comprises two major components, namely, job control and job demand; and added with organizational support. Research questions arise such as, "What is the situation of work condition? What is the contribution of the work condition factors to QWL? Therefore, this study examined the work conditions of Technical analyst of system design personnel based on the job demandcontrol quadrants, and the contribution of the work condition variables to QWL. 


\section{Literature Review}

Quality of Work Life (QWL) is a multi-dimensional construct, made up of a number of interrelated factors. It is associated with job satisfaction, job involvement, motivation, productivity, health, safety and wellbeing, job security, competency development and balance between work and non work life (De Jonge \& Landerweerd, 1993; Hood \& Smith, 1994; European Foundation for the Improvement of Living and Work Conditions, 2002). QWL is also viewed as a wide-ranging concept, which includes adequate and fair remuneration, safe and healthy work conditions and social integration in the work organization that enables an individual to develop and use all his or her capacities. The definitions aim at achieving an effective work environment that meets the organizational and personal needs and values that promote health, well being, job security, job satisfaction, competency development and balance between work and non-work life. The definitions also emphasize good feeling perceived from the interaction between the individuals and the work environment.

With due consideration of the nature of work in computer industry, this study operationally defines QWL as "the effectiveness of the work environment that meets the organizational and personal needs as well as the values of the employees that support and promote better health and well-being, job security, job satisfaction, competency development and balance between work and non-work life". This definition is derived with the aim of gaining leverage in recruiting and retaining valuable workforce as the nature of work continues to diversify.

\section{Need of the study:}

- The Impact of work life reflects in our society.

- Human Perception can be analyzed.

- Effective handling expectation of life in front of industrial demand.

\section{Objectives of study:}

- To know the quality of work life.

- To know the work Environment.

- To know the work factors influence in handling balanced work life.

- To know the psychological factors involved in balanced work life.

- To know the relationship of work environment in quality of work life.

\section{Hypothesis of the study:}

- There is a difference between the level of education and job nature on strategic issues in Computer field.

- There is a difference between the level of education and working flexibility on operational issues in Computer field.

- There is a difference between the level of service and working flexibility on operational issues in Computer field.

\section{Sample design:}

Universe type: Homogeneous and finite.

Sample design type: Random Cluster sampling design.

Sampling units: Selected companies in Bangalore.

Sample size: 250 .

Statistical techniques used: Multiple regression, mean, standard deviation and $\%$ analysis were used.

\section{Research Methodology}

A self administered questionnaire was developed to investigate the job demand, control and support in relation to QWL. Some minor changes to the questionnaire were made after pre-testing. Randomized cluster sampling was utilized to identify the personnel to represent the respective occupational grouping. A total of 300 questionnaires were issued.The data collection by direct interview and telephonic calls. A total of 200 completed questionnaires $(66 \%)$ were used for analysis. The high return rate was obtained due to multiple follow-ups using telephone calls to the contact persons in each organization involved. The data were analyzed using SPSS, specifically the analyses on the profiles and work conditions used simple statistics, and the prediction on QWL used multiple regression technique.

Table 1: Personal Profile of the Respondents $(n=453)$

\begin{tabular}{lllll}
\hline Variables & $\mathrm{n}$ & $\%$ & Mean & SD \\
\hline Gender & & & & \\
Male & 315 & 69.5 & & \\
Female & 138 & 30.5 & &
\end{tabular}




\begin{tabular}{lll} 
Marital Status & & \\
Single & 275 & 60.7 \\
Married & 178 & 39.3 \\
Age (years) & & \\
$\leq 20$ & 5 & 1.1 \\
$21-30$ & 325 & 71.7 \\
$31-40$ & 111 & 24.5 \\
$41-50$ & 8 & 1.8 \\
$\geq 51$ & 4 & 0.9 \\
Educational Level & & \\
Short term courses & 6 & 1.3 \\
Certificates & 24 & 5.3 \\
Diploma & 97 & 21.4 \\
Degree & 255 & 56.4 \\
Post Graduate & 71 & 15.6 \\
\hline
\end{tabular}

Table 2: Professional Profile of the Respondents $(n=453)$

\begin{tabular}{|c|c|c|c|c|}
\hline Variables & $\mathrm{n}$ & $\%$ & Mean & SD \\
\hline \multicolumn{5}{|c|}{ Duration of Computer Use at Home (Hours per day) } \\
\hline$\leq 2.0$ hours & 272 & 60 & 3.05 & 3.21 \\
\hline $2.1-5.0$ hours & 105 & 23.2 & & \\
\hline 5.1-10.0 hours & 57 & 12.6 & & \\
\hline$\geq 10.1$ hours & 19 & 4.2 & & \\
\hline \multicolumn{5}{|l|}{ Work Experience (years) } \\
\hline$\leq 2$ & 95 & 21 & 5.16 & 2.6 \\
\hline $2.1-5.0$ & 171 & 37.7 & & \\
\hline $5.1-10.0$ & 128 & 28.3 & & \\
\hline$\geq 10.1$ & 59 & 13 & & \\
\hline \multicolumn{5}{|c|}{ Work Experience in Current Position (years) } \\
\hline$\leq 2$ & 174 & 38.5 & 3.94 & 2.18 \\
\hline $2.1-5.0$ & 181 & 40 & & \\
\hline $5.1-10.0$ & 70 & 15.5 & & \\
\hline$\geq 10.1$ & 28 & 6 & & \\
\hline \multicolumn{5}{|l|}{ Work Practice } \\
\hline Conventional ( 8 am to $5 \mathrm{pm} /$ day) & 211 & 46.6 & & \\
\hline Shift work (8/9 hours/day) & 91 & 20.1 & & \\
\hline Comprehensive work (5 days/week) & 81 & 17.9 & & \\
\hline Flexible hours (No time limitation/day) & 37 & 10.1 & & \\
\hline Extended hours (12 hours/day) & 24 & 5.3 & & \\
\hline
\end{tabular}

A total of $58.7 \%$ of IS personnel have less than 5 years of total work experience with a mean of work experience of 5.16 years. However, $79 \%$ of the respondents have shown to have less than 5 years of work experience in current work position. This indicates that only $21.5 \%$ of respondents in the industry were those with more than 5 years work experiences. This means that the current workforce in organization is a mixture of new and senior workforce with a ratio of $4: 1$.

Forty-seven percent of personnel engaged in a conventional way of daily working hours ( $8 \mathrm{am}$ to $5 \mathrm{pm}$ ), $20.1 \%$ with shift work (8-9hours/day), $17.9 \%$ with comprehensive work (5 days/week) and $5.3 \%$ with extended working hours (12 hours/day).It has been used to increase the flexibility in working hours in the contemporary organization. The conventional practice of the minimum man hours/day is still emphasized. Only $10 \%$ of the respondents have involved in flexible working hours. Thus, the majority of the IS personnel were based in the workplace engaging in the conventional working hours.

\section{Limitations of the Study}

- Time duration of the study was limited.

- Delegated questions were eliminated.

- In convenient to meet some higher level employees.

\section{Working Condition}

The physical work condition was derived based on the interaction between the means of job demand and job control. Four types of physical work condition, namely, passive (low demand, low control), active (high demand, high control), low strain (low demand, high control) and high strain (high demand and low control) are described in the model .Whereby the physiological work conditions, namely, learning and stress are derived based on the consequences of the level of demand and control in work. Figure 1 reveals physical and physiological conditions of work. The means for job demand $(x=4.37)$ and job control $(x=4.67)$ indicate that related jobs fall in the active quadrant that grouped the IS personnel within an active quadrant .The shortage of skilled personnel, forces the organizations to capitalize on the current workforce for maximum output. They are 
responsible for multitasking with higher workload that demand long hours at workplace. However, the substantial control over their job enables the system personnel to make their own decision on the time, choice of place and method to accomplish the work. The highly demanding with substantial control work condition allows the system personnel to experience continuous learning process. This is accompanied by a higher support level ( $\mathrm{x}=4.67$ ) .Jobs combining high demands, high control and high support would provide the highest level of competence and productivity as they lead to active learning condition. Therefore, IS personnel reported the highest level of personal accomplishment. The finding indicates that high demands are not necessarily harmful if it is accompanied by compatible degree of control and support. This dimension is important among the personnel as their jobs are challenging and require new learning and an active response. The major implication from this study is that a better work condition could be achieved with job redesign not necessarily by decreasing work demands, but by increasing the levels of control and support by the organizations. Given the projected increase in demands for IS jobs coupled with the current government initiatives, the scope of work should focus in providing sufficient control and support. It is also consistent with many other studies which found that job control and support at work were very important dimensions of the psychosocial work environment. Both variables act as a buffer to the demanding work condition. Therefore, the findings show that all the system personnel fall within the active work conditions.

\section{Contributors of QWL}

The knowledge on the significant contributors of QWL would help to derive specific recommendations to improve the QWL among There is a difference between the level of education and working flexibility on operational issues in Computer personnel in India. Table 3 depicts the results of the regression analysis. Three psychosocial variables (as the independent variables) were regressed with QWL (as the dependent variable). Among the three psychosocial variables, organizational support shows the strongest contributor of QWL with a standardized beta of .415 , followed by job control $(\mathrm{beta}=.370$ ) and job demand (beta $=-.141$ ). Organizational support contributes 33\% to QWL. Job control and demand contribute $6.3 \%$ and $1.5 \%$ to QWL, respectively. All the selected psychosocial variables in this research were included in the regression model. This shows that the selected variables were able to significantly predict the variance in QWL.

Table 3: Multiple Regressions of QWL and Components of Work Condition $(\mathrm{n}=453)$

\begin{tabular}{lllll}
\hline Variables & $\mathrm{b}$ & Beta & Adj.r2 & R2 Change \\
\hline Organizational Support & 2.025 & 0.415 & 0.332 & 0.334 \\
Job Control & 1.428 & 0.37 & 0.394 & 0.063 \\
Job Demand & -0.387 & -0.141 & 0.408 & 0.015 \\
Constant & 178.4 & & & \\
\hline
\end{tabular}

$\mathrm{R}=.642 \mathrm{R} 2=.412$ Adj. $\mathrm{R} 2=.408 \mathrm{~F}=114.437$ Sig. $\mathrm{F}=.000$

\section{Discussion, Conclusion and Implication}

The combination of high demand and high control is defined as the active work situation, which creates conducive work environment that heightens the level of motivation and personal growth. When control on the job is high and psychological demands are also high but not overwhelming, learning and growth are the predicted behavioral outcomes. It helps them to learn new things, be creative and develop special abilities. The higher job demand provides an opportunity to experience hands-on skills in problem solving, managing uncertainty, coping strategies and balancing between demand and control. System personnel with this combination of work environment factors have turned out to be the most active group outside of work in social and political activity, in spite of heavy work demands. The active quadrant, allows the system personnel to mobilize more energy to overcome the demand, thus translated into direct action such as problem solving. The situation also predicts the growth and learning stimuli of system personnel which results in high productivity.

It is also consistent with many other studies which found that support at work was a very important dimension of the psychosocial work environment. Both job control and support act as a buffer to the demanding work condition. Organizational support may directly reduce stressor or moderate the stressor-strain relationship. Job demand-control support model also highlighted the similar phenomenon for a demanding work environment. For example, if system personnel experience a high demand on the job but experience a fair amount of support from management and work-peers, the resulting conflict or strain may not occur or it may be reduced. As mentioned in the previous section, system personnel jobs are highly demanding; thus it is appropriate that the organizations take proactive measures to buffer the negative effects of the work environment. This is supported by a high level of organizational support manages to reduce work-family conflict, produce greater job satisfaction and develop greater organizational commitment which would lead to greater QWL.

The moderate to higher level of variety in job dimension is also another factor that can contribute towards QWL among system personnel. Physically, the nature of system personnel job is sitting in front of the 
computer and repetitively using the keyboard and mouse. The nature of active work condition requires them to have continuous improvement and utilization of various new skills and cognitive capability. The nature of job among the IS personnel that associates with greater task variety, task discretion and opportunity to skill development fosters their cognitive and behavioral competency. Indeed, the nature of system related job is complex which includes a substantial amount of task variety in an uncertain work environment. The complexity which is the common feature of system jobs would be one of the sources that provide opportunity for selfdevelopment. It is also reported to provide opportunity for competency development and creativity in the work. This nature of work leads the IS personnel to experience a better QWL.

The discussion suggests that the psychosocial factors are able to predict the QWL among system personnel. The selected socio-demographic variables also play an important role in discussing the relationship and the contribution of the work condition factors to QWL. The findings generally indicate that the Indian core computer field personnel were experiencing a high level of QWL compared to the personnel in the developed countries. The contemporary work environment in India provides more meaningful work to the system personnel compared to the advanced countries. This is indicative of a positive physiological work condition that applies the principles and practices of the concept of QWL. Therefore, it enables the system personnel in India to experience good QWL. The constant review of the changes in the work condition factors due to the advancement in system design and development would enable the maintenance and enhancement of the existing level of QWL. Therefore, it is essential for the human resource practitioners to be alert to the changes of work environment in relation to QWL.

It is concluded that system personnel are enjoying their profession as they have substantial control and support in their job. The selected work condition factors show that to some extent they have influence on QWL. Organizational support, job control and demand are the significant predictors of QWL. Therefore, if these components of work environment are ignored, there would have substantial impact on the QWL of IS personnel. If the system personnel QWL are left unresolved, it would have substantial negative impacts on the overall development of computer sector. Worst still are the mission and vision of the country would remain on the blueprint and the transformation process from the industrial to the knowledge-based society would not be in smooth sailing. Therefore, this type of work practices, even though they are new for India, as the country is still in the early stage of system development, the predictive components should be taken as a precautionary measure in the strategic management planning for the system personnel.

\section{References}

[1]. Publications of the European Communities: Ireland Government of Malaysia (2000). The third outline perspective plan 2001-2010. Economic Planning Unit, Prime Minister's Department, Putrajaya.

[2]. Hackman, J.R., \& Oldham, G.R. (1975). The job diagnostic survey: An instrument for the diagnosis of job and evaluation of job redesign projects (Technical Report 4). Yale University.

[3]. Hofstede, G. (1990). Culture's consequences: International differences in work-related values. Beverly Hills: Sage Publications.

[4]. Hood, J.N., \& Smith, H.L. (1994). Quality of work life in home care. Journal of Nursing Administration, 24, 40-47.

[5]. Jarvenpaa, E., \& Eloranta, E. (2001). Information and communication technologies and quality of working life: Implications for competencies and well-being. In G. Bradley (Ed.) Humans on the net: Information and communication technology, work organization and human beings (pp.109- 118). Stockholm, Sweden: Prevent.

[6]. Johnson, K., Duxbury, L., \& Higgins, C. (1997). Making work and lifestyle initiatives work: Beyond best practices. Ottawa: Industry Canada.

[7]. Karasek, R. \& Theorell, T. (1990). Healthy work. New York: Basic Books.

[8]. Karasek, R. (1979). Job demands, job decision latitude and mental strain: Implications for job redesign. Administrative Science Quarterly, 24, 285-308.

[9]. Karasek, R., \& Theorell, T. (1991). Healthy work stress, productivity, and the reconstruction of working life. New York: Basic Books.

[10]. Kristensen, T.S. (1995). The demand-control-support model: Methodological challenges for future research. Stress Medicine, 11, $17-26$.

[11]. Lau, T., Wong, Y.H., Chan, K.F., \& Law, M. (2001). Information technology and the work environment-Does it change the way people interact at work? Human Systems Management, 20(3), 267-280.

[12]. Leadbetter, C. (1999). Living on thin air. Penguin: London.

[13]. Le Blanc, P.M., De Jonge, J., \& Schaufeli, W.B. (2000). Job stress and health. In introduction to work and organization psychology: A European perspective (pp. 148-177). Blackwell Publisher: Oxford.

[14]. Lu, M.T. (2001). Digital divide in developing countries. Journal of global Information Technology Management, 4(3), 1-4.

[15]. Marmot, M., Siegrist, J., Theorell, T., \& Feeney, A. (1999). Health and the psychosocial environment at work. In M.G. Marmot and R. Wilkinson (Eds.). Social Determinants of Health (pp. 105-132). Oxford University Press: Oxford.

[16]. Martinsons, M.G., \& Cheung, C. (2001). The impact of emerging practices on is specialists: Perceptions, attitude and role changes in Hong Kong. Information and Management, 30, 167-183. 